\title{
FLORISTIC AND FUNCTIONAL COMPARISION OF KARST PASTURES AND KARST MEADOWS FROM THE NORTH ADRIATIC KARST
}

\author{
FLORISTIČNA IN FUNKCIONALNA PRIMERJAVA KRAŠKIH \\ PAŠNIKOV IN KRAŠKIH TRAVNIKOV SEVERNOJADRANSKEGA \\ KRASA
}

\author{
Nataša PIPENBAHER $^{1 \star}$, Mitja KALIGARIČ ${ }^{1}$ \& Sonja ŠKORNIK ${ }^{1}$
}

\begin{abstract}
UDC 633.2.03(497.472)

Nataša Pipenbaher, Mitja Kaligarič \& Sonja Škornik: Floristic and Functional comparision of karst pastures and karst meadows from the North Adriatic Karst

In the present study, we compared the species richness and the floristic and functional composition of two types of extensively managed, species rich dry grasslands (class Festuco-Brometea) from the North Adriatic Karst: karst pastures (alliance Satureion subspicatae) and karst meadows (alliance Scorzonerion villose). Karst pastures are characterized by shallow rocky soils, high $\mathrm{pH}$, and dry, warm conditions, whereas karst meadows have developed on deeper soil, with more humus and moisture and neutral to alkaline $\mathrm{pH}$. The data set included a table with 100 phytosociological relevés of the studied grasslands and a matrix with 15 functional traits determined for 180 plant species. We found high species richness in these grasslands but no statistically significant differences in species richness between karst pastures and meadows. Differences in floristic composition were analysed with Detrended Correspondence Analysis, which supported a clear division between the two vegetation types and indicated that species composition could best be explained in terms of soil humidity and nutrient availability. We also detected several differences in plant functional traits between meadows and pastures. Some of the traits indicate greater resource availability on karst meadows (in particular, high SLA, low LDMC). In contrast, karst pastures have more slow-growing species with a combination of traits that can be interpreted as an avoidance strategy in relation to disturbance (e.g., grazing) in low productive habitats (e.g., low SLA, high LDMC, early flowering species and plants with rosette). A lower relative proportion of competitors (C) and ruderals $(\mathrm{R})$, and a higher relative proportion of stress-tolerators $(\mathrm{S})$ in karst pastures also suggested that these grasslands generally experience higher intensities of stress when compared to karst meadows, presumably owing to lower resource availability on
\end{abstract}

Izvleček UDK 633.2.03(497.472)
Nataša Pipenbaher, Mitja Kaligarič \& Sonja Škornik:
Floristična in funkcionalna primerjava kraških pašnikov in
kraških travnikov severnojadranskega Krasa Predstavljamo rezultate raziskave, v kateri smo primerjali vrstno pestrost, floristično in funkcionalno sestavo med dvema tipoma suhih travišč (razred Festuco-Brometea) severnojadranskega Krasa - kraškimi pašniki (zveza Satureion subspicatae) in kraškimi travniki (zveza Scorzonerion villosae). Za kraške pašnike so značilna plitka kamnita tla $\mathrm{z}$ bazično kemijsko reakcijo in suhe ter tople razmere, medtem ko so kraški travniki razviti na globljih in bolj hranilnih tleh, $\mathrm{z}$ več vlage, kemijska reakcija tal pa je nevtralna do zmerno kisla. Podatki so obsegali tabelo 100 fitocenološkimi popisi kraških pašnikov in travnikov ter matriko s 15 funkcionalnimi potezami, določenimi za 180 rastlinskih vrst. Ugotovili smo visoko vrstno pestrost proučevanih travišč, hkrati pa ni bilo najdenih statistično značilnih razlik v vrstni pestrosti med kraškimi pašniki in kraškimi travniki. Razlike $\mathrm{v}$ floristični sestavi smo ugotavljali z DCA analizo, ki je potrdila jasne razlike med obema vegetacijskima tipoma in nakazala, da se vrstna sestava popisanih sestojev spreminja vzdolž gradientov vlažnosti in hranilnosti tal. Ugotovili smo tudi razlike $\mathrm{v}$ funkcionalnih potezah rastlin med kraškimi travniki in pašniki. Na osnovi nekaterih funkcionalnih potez (zlasti višjih SLA, nižjih LDMC vrednosti) lahko sklepamo, da so kraški travniki bolje založeni s hranili. Kraški pašniki imajo $\mathrm{v}$ primerjavi $\mathrm{z}$ njimi več počasi rastočih vrst $\mathrm{s}$ kombinacijo potez (npr. nizke SLA in visoke LDMC vrednosti, zgodnje cvetenje, rozete), ki jih razlagamo kot strategija izogibanja motnji (npr. paši) v slabo produktivnih habitatih. Tudi nižja deleža kompetitorskih vrst (C) in ruderalk (R) ter hkrati višji delež stres-toleratork ( $\mathrm{S}$ ) na kraških pašnikih potrjujejo, da so v teh habitatih bolj stresne razmere kot na kraških travnikih, kar je po vsej verjetnosti posledica slabše preskrbljenosti rastlin $\mathrm{z}$ vodo in hranilnimi snovmi zaradi kamnitih in plitkih

${ }^{1}$ Biology Department, Faculty of Natural Sciences and Mathematics, University of Maribor, Koroška 160, SI-2000 Maribor, Slovenia, fax: +368225181 80, e-mails: natasa.pipenbaher@uni-mb.si, mitja.kaligaric@uni-mb.si, sonja.skornik@uni-mb.si

Received/Prejeto: 6.2.2011 
stony, shallow soil. We could conclude that karst meadows and pastures differ significantly in both floristic composition and functional trait means, owing to their distinctive land-use (disturbance) and environmental conditions.

Keywords: dry grasslands, plant functional traits, FestucoBrometea, SW Slovenia, DCA, CSR plant strategies. tal. Zaključimo lahko, da obstajajo značilne razlike v floristični in funkconalni sestavi med kraškimi travniki in pašniki kot posledica razlik v rabi (košnja in paša) ter razlik v okoljskih dejavnikih.

Ključne besede: suha travišča, funkcionalne poteze rastlin, Festuco-Brometea, JZ Slovenija, DCA analiza, CSR strategije rastlin.

\section{INTRODUCTION}

The Karst grasslands of the North Adriatic Karst are known as one of the richest plant communities among grasslands (Kaligarič et al. 2006). This diversity has been demonstrated, emphasized and partly explained on many occasions (Horvat \& Horvatić 1934; Ferlan \& Giacomini 1955; Horvatić 1973; Horvat et al. 1974; Poldini 1980; Piskernik 1988; Poldini 1989; Piskernik 1991; Čarni \& Kaligarič 1992; Kaligarič 1994; Kaligarič \& Poldini 1996; Kaligarič 1997; Kaligarič \& Škornik 2002; Pipenbaher et al. 2008; Škornik et al. 2010) in terms of the specific biogeographic position of these grasslands, being in the transitional area of the Mediterranean basin, the Dinaric mountains and Central Europe. The contingent of subMediterranean-Illyrian species is numerous; in addition there are other large interesting contingents of species: e.g., Mediterranean-Pontic or Mediterranean-Pannonian species (Poldini 1989). As has been established by phytosociologists, the internal variability among grasslands is also very high. The North Adriatic grasslands, which all belong to the order Scorzoneretalia villosae Horvatić 1975 (class Festuco-Brometea), were therefore divided in to two separate alliances: Satureion subspicatae Horvat 1962 and Scorzonerion villosae Horvatić 1949 (Kaligarič 1997). The floristic differences between them have already been described as substantial (Kaligarič 1997), and the two alliances have been considered not as biogeographic parallels (as alliances sometimes are), but as ecological parallels (Kaligarič \& Škornik 2002; Kaligarič et al. 2006). The Satureion subspicatae is compost by sclerophyllous plants and represents extensive, semi-natural pasture, whereas Scorzonerion villosae is the more mesophilous alliance, representing extensive unfertilized hay meadows (Kaligarič \& Poldini 1996; Kaligarič 1997).

It should be emphasized that natural conditions on the karst terrain also pre-determine to a considerable extent also the potential land-use of both vegetation types: Scorzonerion villosae grasslands, which appear in the karst polje, sink-holes and within the karst valleys where natural soil accumulation and natural soil fertility are higher, were more prone to mowing. In contrast, the ma- jor management form in the Satureion subspicatae alliance was moderate grazing, as this has developed on the slopes, where because of erosion, soils are shallow and rocky and definitely not convenient for mowing.

It has been well established that differences in essential constraints, e.g. weather, topography, soil conditions and disturbance regime, lead to different plant communities. The species combination assemblage is based on filtering plants with particular sets of functional traits from the available species pools (Lavorel et al. 1997; Lavorel \& Garnier 2002, de Bello et al. 2005). It was emphasized by Keddy (1992), Lavorel et al. (1997) and especially by Diaz et al. (2002) that plant functional traits and their combinations - rather than species identities - are the units that are affected by ecological processes.

In order to gain insight into functional traits, Grime's CSR triangle theory should be considered as well (Pipenbaher et al. 2008). This scheme is built on the assertion that three major determinants of species exist: competition (C), abiotic stress (S) and disturbance (R). The position of any species can be displayed upon a triangular ordination diagram (Grime 1974; Hodgson et al. 1999; Grime 2001). Each strategy is characterized by a distinct set of ecological, morphological and physiological traits and is found in species occupying habitats of a particular kind (Grime et al. 1988).

In the Northern Adriatic Karst area the distinction between pastures and meadows based on plant species composition has been confirmed (Kaligarič 1997), but the degree of functional differentiation between the two grassland types has not yet been considered and documented. Therefore, we would like to answer the following questions: 1 . To what degree do the karst pastures and meadows differ on the basis of their species composition? 2. To what degree - if at all - do they differ on the basis of most important plant functional traits? 3. What could be revealed by a floristic and functional comparison between karst meadows and karst pastures? 4 . What kind of plant ecological strategies are characteristic of karst meadows and karst pastures? 


\section{MATERIALS AND METHODS}

\section{STUDY AREA}

Slovenia, situated at ca. $46^{\circ} \mathrm{N}, 14^{\circ} \mathrm{E}$ in the contact area between the Alps, the Dinarides, and the Mediterranean and Pannonia plains, has a relief consisting of plains, hilly regions, highlands, mountains etc. $40 \%$ of the land is underlain by carbonate rocks, mainly well karstified and dolomitised (Watts 2004).

The position of the study area lies between the Adriatic Sea and the Pre-Dinaric region in Slovenia. It represents the most north-western part of the Balkan Peninsula. It consists of the limestone Karst plateau (Low Karst) and mountains (High Karst). The Karst Plateau is $100-500 \mathrm{~m}$ a.s.l. and is characterized by its geomorphological phenomena (rocks, karst poljes, dolinas, caves, etc.) (Mihevc 1997). The climate is sub-Mediterranean (Ogrin 1995). Precipitation varies from $1,356 \mathrm{~mm}$ and up to $1,781 \mathrm{~mm}$ on the High Karst. The strong bora wind causes desiccation and erosion. The mean annual temperature is $8.5^{\circ} \mathrm{C}$ (ARSO 2009). Poldini (1989) characterized the climate as transitional between Mediterranean and continental pre-Alpine, with rainy cool winters and long, dry summers.

Floristically the study area is a contact area between the Mediterranean and Euro-Siberian biogeographical zones, having characteristics of both zones. The natural vegetation is deciduous forest, constituted by various species of oak (Quézel \& Medail 2003). Mixed deciduous thermophilous woodlands prevail at lower altitudes up to $800-1,000 \mathrm{~m}$. In this belt tree species such as Quercus pubescens, Carpinus orientalis, Ostrya carpinifolia, Fraxinus ornus and, rarely, Acer monspessulanum and Pistacia terebinthus constitute the sub-Mediterranean vegetation below the beech forest zone. Temperate deciduous trees such as beech nowadays represent the higher altitudinal belt above 800 $1,000 \mathrm{~m}$. The derivates of the deciduous forests are dry and semi-dry grasslands of the order Scorzoneretalia villosae Horvatić 1975 (class Festuco-Brometea) (Kaligarič 1997). Most of the non-forest vegetation belongs to pastures (alliance Satureion subspicatae Horvat 1962). The association Carici-Centaureetum rupestris Horvat 1931 is the most widespread and common in the study area. It is characterized by shallow rocky soils, high $\mathrm{pH}$, and dry, warm conditions. Productivity is very low. Due to hydric stress, the vegetation becomes almost completely dry in the summer (Kaligarič 1997). Dry and semi-dry meadows (alliance Scorzonerion villosae Horvatić 1949), association Danthonio-Scorzoneretum villosae Horvat et Horvatić (1956) 1958 have developed on deeper soil, where there are more humus and moisture and neutral to alkaline $\mathrm{pH}$ (Kaligarič et al. 2006).

\section{VEGETATION SURVEY}

We analysed 48 relevés of karst meadows - association Danthonio-Scorzoneretum villosae (relevés from 1-48 (Tab. 1) are in book Kaligarič 1997) and 52 relevés of karst pastures - association Carici-Centaureetum rupestris Horvat 1931 (relevés from 10-62 (Tab. 4) are in Kaligarič 1997). On each site, vascular plants were sampled using a seven-point species cover-abundance scale ( $r,+, 1$ to 5$)$, according to the Braun-Blanquet method (Braun-Blanquet 1964, Westhoff \& Van der Maarel 1973, Dierschke 1994) within 5 x 5 m quadrates (relevés). Plant species richness was noted as the number of species recorded in each relevé. Taxonomic nomenclature follows Martinčič et al. (2007); syntaxonomic nomenclature follows Kaligarič (1997).

\section{PLANT FUNCTIONAL TRAITS}

In choosing key traits, we followed various literature sources (Hodgson et al. 1999; Kahmen et al. 2002; Cornelissen et al. 2003). We selected 15 traits for each species. Traits were chosen from our own database (protocol standardized by Cornelissen et al. 2003). Information on species traits was also taken from two existing trait databases: BiolFlor (Klotz et al. 2002) and LEDA (Kleyer et al. 2008). Species were characterized by basic traits as well as composite traits (such as C-S-R strategy). Owing to the variety of species sets, we focused on traits that were easy to measure. The traits selected were as follows: "life form", "life cycle", "growth form", "spinescence", "hairiness", "plant height", "specific leaf area (SLA)", leaf dry matter content (LDMC)", "flowering start", "flowering end", "flowering period", "leaf persistence", "leaf anatomy", "leaf form" and "CSR strategy".

The CSR strategy scheme provides a system for classifying herbaceous plants as having strategies adapted to intense competition (C), abiotic stress (S) and frequent disturbance (R) (Grime 1974; McIntyre et al., 1995; Lavorel et al. 1997; Westoby 1998). To determine CSR functional types for 122 plant species recorded in 100 analysed vegetation relevés, we used a rapid method published by Hodgson et al. (1999).

The list of traits with the description of classes in the matrix and the sources of information are presented in Tab. 1. Categorical traits were all transformed into binary variables, with one for each possible level of the factor. In this way the number of traits in the matrix increased from 15 to 37. For plant abundance, data from the seven-point Braun-Blanquet ordination scale were first converted into a 1 to 7 scale (Pyšek \& Pyšek 1991). All plant species occurring only in one relevé were removed to exclude casual occurrences from the analysis. 
Tab. 1: Plant traits, recorded on 180 vascular plant species from karst meadows and karst pasture (SW Slovenia). Scales of measurement were originally categorical (cat), continuous (cont) or binary (bin).

\begin{tabular}{|c|c|c|}
\hline Traits & Abbreviation and description & Data source \\
\hline Life form & $\begin{array}{l}\text { LF_Ge }=\text { geophytes; } \\
\text { LF_He = hemicryptophytes }\end{array}$ & $\begin{array}{l}\text { Hegi 1958, 1963, 1964, 1965, 1966, 1974, 1987; Martinčič } \\
\text { et al. } 2007\end{array}$ \\
\hline Life cycle & $\begin{array}{l}\text { LC_Annu = annual; LC_Bien = biennial; } \\
\text { LC_Pere = perennial }\end{array}$ & $\begin{array}{l}\text { Hegi 1958, 1963, 1964, 1965, 1966, 1974, 1987; Martinčič } \\
\text { et al. } 2007\end{array}$ \\
\hline Growth form & $\begin{array}{l}\text { GF_Tuss = tussocks; GF_Rose }=\text { rosette; } \\
\text { GF_le_st = leafy stem; GF_ro_le }=\text { rosette } \\
\text { and leafy stem }\end{array}$ & $\begin{array}{l}\text { Hegi 1958, 1963, 1964, 1965, 1966, 1974, 1987; Martinčič } \\
\text { et al. 2007; Rothmaler } 1995\end{array}$ \\
\hline Spinescence & Spi_pres $=$ present; Spine_0 = none & $\begin{array}{l}\text { Hegi 1958, 1963, 1964, 1965, 1966, 1974, 1987; Martinčič } \\
\text { et al. } 2007\end{array}$ \\
\hline Hairiness & $\begin{array}{l}\text { Hair_low }=\text { low; Hair_hig }=\text { high; } \\
\text { Hair_0 = no }\end{array}$ & $\begin{array}{l}\text { Hegi 1958, 1963, 1964, 1965, 1966, 1974, 1987; Poldini } \\
\text { 1991; Martinčič et al. } 2007\end{array}$ \\
\hline Plant height & Plan_hig $=\mathrm{cm}$ & Own measurements \\
\hline Specific leaf area & $\mathrm{SLA}=\mathrm{mm}^{2} / \mathrm{mg}$ & Own measurements; LEDA database (Kleyer et al. 2008) \\
\hline Leaf dry matter content & $\mathrm{LDMC}=\mathrm{mg} / \mathrm{g}$ & Own measurements; LEDA database (Kleyer et al. 2008) \\
\hline Flowering start & Flo_star $=$ months & $\begin{array}{l}\text { Hegi 1958, 1963, 1964, 1965, 1966, 1974, 1987; Poldini } \\
\text { 1991; Martinčič et al. } 2007\end{array}$ \\
\hline Flowering end & Flo_end = months & $\begin{array}{l}\text { Hegi 1958, 1963, 1964, 1965, 1966, 1974, 1987, Poldini } \\
\text { 1991; Martinčič et al. } 2007\end{array}$ \\
\hline Flowering period & Flo_peri $=$ months & $\begin{array}{l}\text { Hegi 1958, 1963, 1964, 1965, 1966, 1974, 1987; Poldini } \\
\text { 1991; Martinčič et al. } 2007\end{array}$ \\
\hline Leaf persistence & $\begin{array}{l}\text { LP_1 = spring green; LP_2 = summer green; } \\
\text { LP_3 = overwintering green; } \\
\text { LP_4 = persistent green }\end{array}$ & Own measurements; BiolFLor (Klotz et al. 2002) \\
\hline Leaf anatomy & $\begin{array}{l}\text { LA_2 = scleromorphic } \\
\text { LA_3 }=\text { mesomorphic }\end{array}$ & Own measurements; BiolFLor (Klotz et al. 2002) \\
\hline Leaf form & $\begin{array}{l}\text { Lea_for3 = grass-like; Lea_for } 4=\text { long- } \\
\text { leaf; Lea_for5 = simple; Lea_for7 = lobate; } \\
\text { Lea_for8 = pinnatifid; Lea_for } 10=\text { palmate; } \\
\text { Lea_for } 11=\text { pinnate; Lea_for } 12=\text { bipinnate }\end{array}$ & BiolFLor (Klotz et al. 2002) \\
\hline C-S-R strategy & $\begin{array}{l}C=\text { competitors } ; S=\text { stress-tolerators; } \\
R=\text { ruderals }\end{array}$ & Own measurements \\
\hline
\end{tabular}

To assess the functional trait composition of relevés, we combined the species by relevés matrix with the corresponding species by traits matrix. This was done by calculating the community-weighted mean trait values (CWM) for each relevé as the average of trait values weighted by the relative abundance of each species (Garnier et al. 2004; Lepš et al. 2006; Lavorel et al. 2008; Moretti et al. 2009; Ricotta \& Moretti 2010). The metric is computed simply as

$$
C W M_{j k}=\sum_{i=1}^{S} p_{i k} \times x_{i j}
$$

where $\mathrm{CWM}_{\mathrm{jk}}$ is the community-weighted mean value of trait $j$ at site $k ; p_{i k}$ is the relative abundance of species $i(\mathrm{i}=1,2, \ldots ., \mathrm{S})$ at site $\mathrm{k}$; and $\mathrm{x}_{\mathrm{ij}}$ is the value of trait j for species i (Ricotta \& Moretti 2010). This operation results in 37 new traits by 100 relevés matrix (matrix CWM).

\section{STATISTICAL ANALYSIS}

Detrended Correspondence Analysis (DCA, Hill \& Gauch 1980) ordination was applied to the species-relevés matrix. The intention was to provide a visual representation of differences in floristic composition between the two vegetation types being studied.

To test differences in the specific plant functional traits between karst meadows and karst pastures, the CWM values of all 37 functional traits were analysed with a Student's t-test for independent samples (SPSS Inc. 2006). Only traits ( $n=29$, Tab. 2$)$ with significant differences in their CWM values between karst meadows 
and karst pastures (Student's t-test) were used for further analysis.

The CWM matrix was further analysed by means of Principal Component Analysis (PCA) (Goodall 1954). Gradient length for the first PCA axis of ordination was
0.22 , indicating that linear ordination methods are suitable for the analysis.

The ordination methods (PCA, DCA) and visualization of their results were carried out using the Canoco and CanoDraw programs (ter Braak \& Šmilauer 2002).

\section{RESULTS}

\section{SPECIES RICHNESS AND SPECIES COMPOSITION}

The total number of vascular plant species recorded in 100 relevés of these particular karst grasslands was 180, with 144 on karst meadows (mean $=34 \pm 5,6 \mathrm{~s}$. d. per relevé, $\mathrm{N}=48$ ) and 134 (mean $=31 \pm 8.7$ s.d. per relevé, $\mathrm{N}=52$ ) on karst pastures. We found no statistically significant differences in species richness between the grassland types $(\mathrm{P}=0.100)$. All species are listed in Appendix 1. There are 98 common species, 46 species exclusive to the karst meadows and 36 exclusive to the karst pastures.

Differences in floristic composition were first analysed with DCA analysis of the 180 species $\mathrm{x} 100$ relevés matrix. Eigenvalues for first two DCA axes are 0.530 and 0.271 . The first two axes together explain $23.8 \%$ of the variability in the species composition. DCA ordina- tion is shown in Fig. 1. The DCA Axis 1 of this analysis showed evident divergence, which supports a clear division between these two grassland types: karst pastures and karst meadows. The species with the lowest scores (-X) are those frequent in karst meadows, such as Dactylis glomerata, Ononis antiquorum, Peucedanum cervaria, Chrysopogon gryllus, Galium verum. Species that are associated with relevés of karst pastures received the highest scores $(+\mathrm{X})$ in the first DCA: for example, Globularia cordifolia, Anthyllis jacquenii, Satureja liburnica, Sesleria juncifolia, Genista sericea and Plantago argentea.

\section{PLANT FUNCTIONAL TRAIT COMPOSITION}

In order to identify differences in plant trait composition between karst meadows and pastures, the CWM matrix was analyzed with PCA. The ordination graph is presented in Fig. 2, where only traits with significant differences in their CWM values ( $\mathrm{n}=29$, Tab. 2) between karst pastures and meadows are shown. Relevés of both veg-

Fig. 1: DCA ordination diagram of matrix with 100 relevés $x 180$ species. Eigenvalues: Axis $1=0.530$; Axis $2=0.171 ; 23.8 \%$ of variance in species explained by both axes. Shown species have the highest weight.

Legend: - karst meadows; O - karst pastures. Abbreviations of species explained in Appendix 1. Relevé numbers correspond to those in the Appendix 1. 


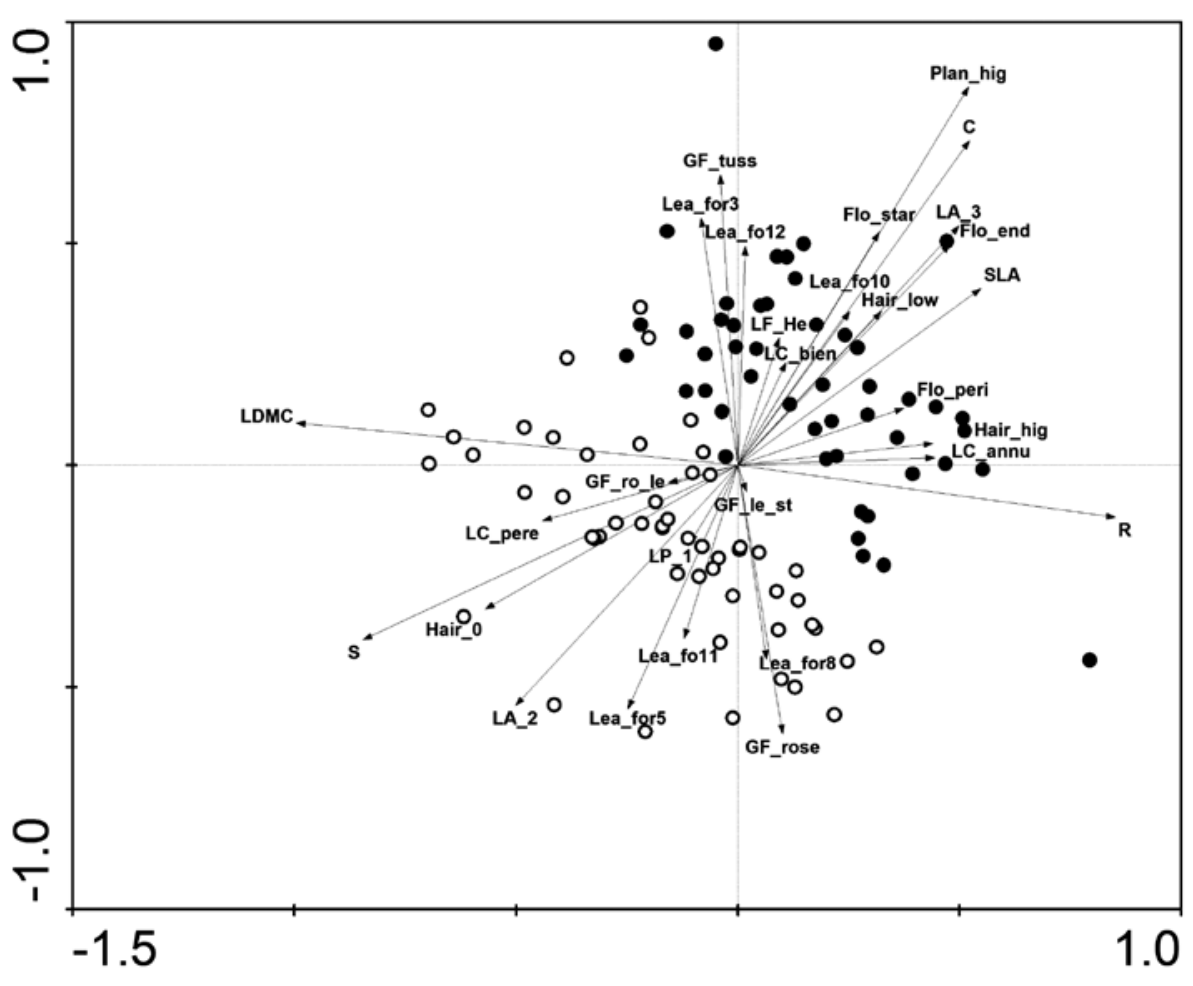

\begin{tabular}{|c|c|c|c|c|}
\hline Plant functional traits & Species abbreviations & Karst meadows & Karst pastures & $p$ \\
\hline Life form & LF_He & 0.9923 & 0.9824 & $* * *$ \\
\hline Life cycle & $\begin{array}{l}\text { LC_Annl } \\
\text { LC_Bien } \\
\text { LC_Pere }\end{array}$ & $\begin{array}{l}0.0343 \\
0.0128 \\
0.9528\end{array}$ & $\begin{array}{l}0.0191 \\
0.0027 \\
0.9782\end{array}$ & $\begin{array}{l}* * \\
* * * \\
* * *\end{array}$ \\
\hline Growth form & $\begin{array}{l}\text { GF_Tuss } \\
\text { GF_Rose } \\
\text { GF_le_st } \\
\text { GF_ro_le }\end{array}$ & $\begin{array}{l}0.3088 \\
0.1164 \\
0.4707 \\
0.1003 \\
\end{array}$ & $\begin{array}{l}0.2274 \\
0.1461 \\
0.5062 \\
0.1203 \\
\end{array}$ & $\begin{array}{l}* * \\
* \\
* \\
*\end{array}$ \\
\hline Hairiness & $\begin{array}{l}\text { Hair_low } \\
\text { Hair_hig } \\
\text { Hair_0 }\end{array}$ & $\begin{array}{l}0.4355 \\
0.2233 \\
0.3411 \\
\end{array}$ & $\begin{array}{l}0.3751 \\
0.1700 \\
0.4548 \\
\end{array}$ & $\begin{array}{l}* * * * \\
* * * \\
* * *\end{array}$ \\
\hline Plant height & Plan_hig & 39.23 & 25.76 & $* * *$ \\
\hline Specific leaf area & SLA & 14.55 & 13.00 & $* * *$ \\
\hline Leaf dry matter content & LDMC & 307.57 & 325.76 & $* * *$ \\
\hline Flowering start & Flo_star & 5.5131 & 5.2079 & $* * *$ \\
\hline Flowering end & Flo_end & 7.8051 & 7.3367 & $* * *$ \\
\hline Flowering period & Flo_peri & 3.3085 & 3.1524 & $* * *$ \\
\hline Leaf persistence & LP_1 & 0.0115 & 0.0263 & $* * *$ \\
\hline Leaf anatomy & $\begin{array}{l}\text { LA_2 } \\
\text { LA_3 }\end{array}$ & $\begin{array}{l}0.5001 \\
0.4987\end{array}$ & $\begin{array}{l}0.6730 \\
0.3248\end{array}$ & $\begin{array}{l}* * * \\
* * * \\
\end{array}$ \\
\hline Leaf form & $\begin{array}{l}\text { Lea_for3 } \\
\text { Lea_for5 } \\
\text { Lea_for8 } \\
\text { Lea_for10 } \\
\text { Lea_for11 } \\
\text { Lea_for12 }\end{array}$ & $\begin{array}{l}0.2819 \\
0.1675 \\
0.0456 \\
0.1239 \\
0.0549 \\
0.0399 \\
\end{array}$ & $\begin{array}{l}0.2289 \\
0.2408 \\
0.0663 \\
0.0728 \\
0.0794 \\
0.0258 \\
\end{array}$ & $\begin{array}{l}* * * \\
* * * \\
* * \\
* * * \\
* * \\
*\end{array}$ \\
\hline C-S-R strategy & $\begin{array}{l}\mathrm{C} \\
\mathrm{S} \\
\mathrm{R}\end{array}$ & $\begin{array}{l}0.5193 \\
0.2684 \\
0.2105 \\
\end{array}$ & $\begin{array}{l}0.4360 \\
0.3970 \\
0.1657 \\
\end{array}$ & $\begin{array}{l}* * * * \\
* * * \\
* * * \\
\end{array}$ \\
\hline
\end{tabular}

${ }^{*}<0.05,{ }^{* *}<0.01,{ }^{* * *}<0.001$
Fig. 2: PCA ordination diagram of CWM matrix with 100 relevés of karst meadows $(N=48)$ and pastures $(N=52)$ and plant functional traits. Only traits $(n=29)$ with significant differences in their CWM values between karst meadows and karst pastures (Student's t-test) are shown. Eigenvalues: Axis $1=0.86$; Axis $2=0.14$.

Legend: - karst meadows; O - karst pastures. Abbreviations of plant traits explained in Tab. 1 .
Tab. 2: Traits with significant differences in their CWM values between karst meadows $(N=48)$ and karst pastures $(N=52)$ (Student's t-test). Values in the table represent the mean of the CWM values of each trait in both groups of relevés. 
etation types are again clearly divided, which indicates that the karst pastures and meadows contain species with distinct plant functional traits. A t-test showed that karst meadows had significantly higher mean plant height (Plan_hig), SLA values, hemicryptophytes (LF_He), annuals (LC_annu) and biennials (LC_bien), proportion of hairy plants (Hair_low, Hair_hig), a tussock growth form (GF_tuss) and a grass-like or palmate leaf form (Lea_for3, Lea_for10) (Tab. 2). In karst meadows, species begin to flower later (Flo_star) and have a longer flowering period (Flo_peri) than in pastures. In contrast, karst pastures have a higher proportion of peren-

\section{DISCUSSION AND CONCLUSIONS}

\section{SPECIES RICHNESS AND SPECIES COMPOSITION}

Calcareous dry grasslands (Festuco-Brometea) are known as particularly species-rich habitats (in vascular plants, bryophytes and animals), and they thus host a considerable proportion of Europe's biodiversity (Willems 1990). They are among the most species-rich plant communities in Europe in terms of the number of plant species they support per unit area (Wallis DeVries et al. 2002).

Our study also found high species richness in both karst meadows and pastures (on average of 34 and 31 species per $25 \mathrm{~m}^{2}$, respectively), whereas basic comparisons between the two grassland types showed a rather uniform view of species richness. Many studies have examined the influence of different management regimes on grassland vegetation (e.g., Diaz et al. 2001; del Pozo et al. 2006; Škornik et al. 2010). However, only a few of them directly compare grazing and mowing. Stammel et al. (2003) found that plant species richness on mown straw meadows was significantly higher than on pastures (in number of species per plot and per site). Hansson \& Fogelfors (2000) also detected slightly more species on mown semi-natural grasslands in Sweden, whereas Gutser \& Kuhn (1998) found no difference between mown and grazed grasslands. In contrast, Schläpfer et al. (1998) found significantly more species on grazed xeric grasslands than on mowed sites. In our case, the slightly higher species diversity of meadows is probably connected with their more favorable conditions for plant growth and/or establishment, owing to their more humid and nutrient-rich soil.

As expected and already documented in other studies (Kaligarič 1997; Kaligarič \& Škornik 2007), we found evident differences in floristic composition between karst meadows and pastures, with a floristic similarity of nials (LC_pere), early flowering species (Flo_star), plants with rosette (GF_Rose), spring green and scleromorphic leaves (LP_1, LA_2). Plants in pastures are also characterized by significantly higher LDMC values, simple (Lea_for5), pinnatifid (Lea_for8) and pinnate leaf forms (Lea_for11) (Tab. 2).

The comparison of relative proportions of C, S and $\mathrm{R}$ strategists among relevés showed significantly higher relative proportions of competitors (C) and ruderals (R) in karst meadows than in pastures. Pastures, in contrast had significantly higher proportions of stress-tolerators (S) when compared to karst meadows (Tab. 2).

approx. 54\%. Frequent common species, such as Bromus erectus, Carex humilis, Dorycnium germanicum, Briza media, Salvia pratensis agg., Buphthalmum salicifolium, Asperula cynanchica, Galium verum, Brachypodium rupestre, Hypochoeris maculata, Betonica officinalis subsp. serotina, etc., represent plants characteristic of the European secondary dry and semi-dry grasslands of the phytosociological class Festuco-Brometea (Dierschke 1997; Kaligarič 1997; Škornik 2001; Kaligarič \& Škornik 2002; Illyés et al. 2007). As DCA ordination of species showed (Fig. 2), differences in floristic composition between karst meadows and pastures are probably related to soil conditions in the grasslands: soil $\mathrm{pH}$, moisture, available nutrients, etc. Species composition of meadows included many species characteristic of mesotrophic meadows from the class Molinio-Arrhenatheretea and which were missing in karst pastures: for example Carex flacca, Tragopogon pratensis, Lathyrus pratensis and Leontodon hispidus. These species occur in karst meadows because of the more mesic soil conditions (with more humus and moisture and neutral to slightly acid $\mathrm{pH}$ ). In contrast, karst pastures are developed on shallower, stonier soils, where bedrock reaches the surface and enables the occurrence of many typical oligotrophic, thermophilous, sclerophyllous and basiphilous species, such as Sesleria juncifolia, Carex humilis, Centaurea rupestris, Satureja subspicata subsp. liburnica, Crepis chondrilloides, Gentiana tergestina, Globularia cordifolia, Genista sericea and Plantago argentea.

\section{PLANT FUNCTIONAL TRAIT COMPOSITION}

In addition to differences in species composition, we also detected several differences in the plant functional traits between karst meadows and pastures. Our results are 
consistent with previous assertions that grazing generally favoured small-stature species and species with rosette over high, erect and tussock plants (Harper 1969; Lavorel et al. 1997; Diaz et al. 2001; Peco et al. 2005; Diaz et al 2007). In pastures, tall, erect plants are eliminated by large herbivore grazing, while small or prostrate species survive (McIntyre et al. 1995).

Our study showed that forbs with a perennial life cycle predominated in pastures and meadows. Annuals that reproduce generatively and can quickly colonize gaps were rare in both grassland types. The small numbers of species with short life span was probably due to the low intensity of land use. It has been shown in other studies that annuals (therophytes) are promoted by intensification of land use (Bullock et al. 1994; McIntyre et al. 1995; Škornik et al. 2010), as they are more tolerant of disturbance, owing to their fast growth rates and early, prolific seed set (Grime 1974).

LDMC and SLA were also traits that differ significantly between karst pastures and meadows. Species in pastures showed lower SLA values and higher LDMC values. Lower values of SLA tend to correspond with relatively high investment in "leaf defence" and long leaf lifespan; whereas leaves with high LDMC tend to be relatively tough and are thus assumed to be more resistant to physical hazards (e.g. herbivory, wind, hail...) (Cornelissen et al. 2003). Species with low LDMC and high SLA tend to be associated with productive, often highly disturbed environments. Our results partially concur with those of Diaz et al. (2001) and Westoby's (1998) suggesting that a higher growth rate (high SLA) is a disturbance tolerance mechanism, whereas small leaves are an avoidance mechanism (Briske 1996). A similar interpretation could also be used for traits connected to reproductive strategies. In our study, early flowering and fruiting ap- peared to be promoted in karst pastures. These traits have been interpreted as an avoidance strategy in relation to grazing (Briske 1996). Furthermore, reproductive strategies can be considered as an example of adaptation to both climate and grazing (de Bello et al. 2005). In our case, earlier flowering in karst pastures, when compared to the more mesophilous karst meadows, is probably an example of adaptation to more arid microclimate conditions.

Grime's (1974) CSR triangle provides a system for classifying herbaceous plants as having strategies adapted to intense competition (C), abiotic stress (S) and frequent disturbance (R). The grassland communities of the north Adriatic Karst comprise species with pronounced competitive (C) characteristics. Especially in the case of meadows, they appeared to provide sufficient resources to support tall, fast growing competitors. In general, the competitive nature of species is restricted by disturbance and stress conditions. In these grasslands, stress is more severe in karst pastures owing to their extremely shallow and stony dry soils, which experience desiccation during the summer. The low relative proportions of ruderals (R) for both karst pastures and meadows also suggest the reduced impact of disturbance, owing to low intensity land-use (mowing and grazing).

We could conclude that karst meadows and pastures differ significantly in both floristic composition and functional trait means, owing to different environmental conditions (e.g., topography and soil conditions) and different land-use (disturbance). DCA analysis of species composition and some of the traits indicated greater resource availability on karst meadows. In contrast, karst pastures showed more species with combination of traits interpreted as an avoidance strategy in relation to disturbance in low productive habitats.

\section{REFERENCES}

ARSO, 2009: Meteorološki letopis - mesečna višina padavin.- [Online] Available from: http://www.arso. gov.si/vreme/podnebje/meteorolo\%c5\%a1ki\%20 letopis/2009pad_vis.pdf [Accesses 24 ${ }^{\text {th }}$ October 2011].

ARSO, 2009: Meteorološki letopis - mesečna višina padavin.- [Online] Available from: http://www.arso. gov.si/vreme/podnebje/meteorolo\%c5\%a1ki\%20 letopis/2009mes_1.pdf [Accesses 24 ${ }^{\text {th }}$ October 2011].
Braun-Blanquet, J., 1964: Pflanzensoziologie. Grundzüge der Vegetationskunde.- Springer Verlag, pp. 864, Wien.

Briske, D.D., 1996: Strategies of plant survival in grazed systems: A functional interpretation.- In: Hodgson, J.G. et al. (eds.) The ecology and managment of grazing systems. CAB International, pp. 37-66, Oxon.

Bullock, J.M., Clear Hill, B., Dale, M.P. \& J. Silvertown, 1994: An experimental study of the effects of sheep grazing on vegetation change in a species-poor grassland and the role of seedling recruitment into gaps.- Journal of applied ecology, 31, 493-507. 
Cornelissen, J.H.C., Lavorel, S., Gernier, E., Diaz, S., Buchmann, N., Gurvich, D.E., Reich, P.B., ter Steege, H., Morgan, H.D., van der Heijden, M.G.A., Pausas, J.G. \& H. Poorter, 2003: A handbook of protocols for standardised and easy measurement of plant functional traits worldwide.- Australian Journal of Botany, 51, 335-380.

Čarni, A. \& M. Kaligarič, 1992: Study of the succession line from abandoned "terraced" vineyards in NW Istria (Slovenia).- In: Colloquio (ed.) Approcci metodologici per la definizione dell ambiente fisico $e$ biologico mediterraneo: seminario scientifico-tecnico di Lecce, $17^{\text {th }}-19^{\text {th }}$ November 1992, Castro Marina, 253-264, Castro Marina.

de Bello, F., Lepš, J. \& M.T. Sebastia, 2005: Predictive value of plant traits to grazing along a climatic gradient in the Mediterranean.- Journal of applied Ecology, 42, 824-833.

del Pozo, A., Ovalle, C., Casado, M., Acosta, B. \& J.M. de Miguel, 2006: Effects of grazing intensity in grasslands of the Espinal of central Chile.- Journal of Vegetation Science, 17, 791-798.

Diaz, S. \& M. Cabido, 2001: Vive la différence: plant functional diversity matters to ecosystem processes.- Trends in Ecology and Evolution, 16, 646-655.

Diaz, S., McIntyre, S., Lavorel, S. \& J.G. Pausas, 2002: Does hairiness matter in Harare? Resolving controversy in global comparisons of plant trait responses to ecosystem disturbance.- New Phytologist, 154, 7-9.

Diaz, S., Lavorel, S., de Bello, F., Quetier, F., Grrigulis, K., \& M. Robson, 2007: Incorporating plant functional diversity effects in ecosystem service assessments.Proseedings of the National Academy of Sciences of the United States of America, 104, 20684-20689.

Dierschke, H., 1994: Pflanzensoziologie: Grundlage und Methode.- Ulmer, pp. 683, Stuttgart.

Dierschke, H., 1997: Pflanzensoziologisch-synchorologische Stellung des Xerothermgraslandes (FestucoBrometea) in Mitteleuropa.- Phytocoenologia, 27, 2, 127-140.

Ferlan, L. \& V. Giacomini, 1955: Appunti fitosocialogici su esempi di pascolo carsico Chrysopogono-Centaureetum cristatae.- Atti I Convegno Friul. Sc. Nat. Udine, 4-5, 159-183.

Garnier, E., Cortez, J., Billes, G., Navas, M.L., Roumet, C., Debussche, M., Laurnet, G., Blanchard, A., Aubry, D., Bellmann, A., Neill, C. \& J.P. Toussaint, 2004: Plant functional markers capture ecosystem properties during secondary succession.- Ecology, 85, 2630-2637.
Goodall, D.W., 1954: Objective methods for the classification of vegetation. II. An essay in the use of factor analysis.- Australian Journal of Botany, 2, 304-324.

Grime, J.P., 1974: Vegetation classification by reference to strategies.- Nature, 250, 26-31.

Grime, J.P., Hodgson, J.G. \& R. Hunt, 1988: Comparative plant ecology.- Unwin Hyman Ltd., pp. 752, London.

Grime, J.P., 2001: Plant Strategies, Vegetation Processes, and Ecosystem Properties.- Wiley \& Sons, pp. 417, Chichester.

Gutser, D. \& J. Kuhn, 1998: Schaf- und Ziegenbeweidung ehemaliger Mähder (Buckelwiesen bei Mittenwald): Auswirkungen auf Vegetation und Flora, Empfehlungen zum Beweidungsmodus.- Z. Ökol. Natursch, 7, 85-97.

Hansson, M., \& H. Fogelfors, 2000: Managment of a semi-natural grassland; results from a 15-year-old experiment in southern Sweden.- Journal of vegetation science, $11,31-38$.

Harper, J.L., 1969: The role of predation in vegetational diversity. Diversity and stability in ecological systems.- Brookhaven Symposium in Biology, 22, 4862.

Hegi, G., 1958: Illustrierte Flora von Mittel-Europa.- Band IV, 1. Teil. Carl Hanser Verlag, pp. 70, München.

Hegi, G. 1963: Illustrierte Flora von Mittel-Europa. Band III, 1. Teil. Carl Hanser Verlag, pp. 452, München.

Hegi, G., 1964: Illustrierte Flora von Mittel-Europa. Band V, 4. Teil. Paul Parey Verlag, pp. 2255-2645, BerlinHamburg.

Hegi, G., 1965: Illustrierte Flora von Mittel-Europa. Band I. Carl Hanser Verlag, pp. 528, München.

Hegi, G., 1966: Illustrierte Flora von Mittel-Europa. Band IV, 2. Teil. Carl Hanser Verlag, pp. 448, München.

Hegi, G., 1974: Illustrierte Flora von Mittel-Europa. Band VI/3.Teil. Verlag Paul Parey, pp. 366, Berlin-Hamburg.

Hegi, G., 1987: Illustrierte Flora von Mittel-Europa. Band VI, 3. Teil. Paul Parey Verlag, pp. 320, Berlin-Hamburg.

Hill, M.O. \& H.G. Gauch, Jr., 1980: Detrended Correspondence Analysis: an improved ordination technique.- Vegetatio, 42, 47-58.

Hodgson, J.G., Wilson, P.J., Hunt, R., Grime, J.P. \& K. Thompson, 1999: Allocating C-S-R plant functional types: a soft approach to a hard problem.- Oikos, $85,282-294$.

Horvat, I. \& S. Horvatić, 1934: Chrysopogoneto-Satureion subspicatae - ein neuer Verband der Brometalia erecti Braun-Blanquet.- Acta Botanica inst. Bot. Univ- Zagrebensis, 4, 8-12. 
Horvat, I., Glavač, V. \& E. Ellenberg, 1974: Vegetation Sudosteuropas.- Gustav Fischer Verlag, pp. 768, Stuttgart.

Horvatić, S., 1973: Syntaxonomic analysis of the vegetation of dry grasslan and stony meadows in eastern Adriatic coastal karst district based on the latest phytocoenological research.- Fragmenta Herbologica Jugoslavica, 32, 1-15.

Illyés, E., Chytrý, M., Botta-Dukát, Z., Jandt, U., Škodová, I., Janišová, M., Willner, W. \& O. Hájek, 2007: Semidry grasslands along a climatic gradient across Central Europe: Vegetation classification with validation.- Journal of Vegetation Science, 18, 6, 835-846.

Kahmen, S., Poschlod, P. \& K. Schreiber, 2002: Conservation management calcareous grasslands. Changes in plant species composition and response of functional traits during 25 years.- Biological Conservation, 104, 319-328.

Kaligarič, M., 1994: Asociacija Genisto sericeae - Seslerietum juncifoliae Poldini 80 (združba svilnate košeničnice in ozkolistne vilovine) v Sloveniji.- Annales, 4, 83-86.

Kaligarič, M. \& L. Poldini, 1996: New contribution on the typology of the vegetation of dry grasslands Scorzoneretalia villosae $\mathrm{H}$-ić 1975 in the north Adriatic Karst.- Gortania, 19, 119-148.

Kaligarič, M., 1997: Rastlinstvo Primorskega krasa in Slovenske Istre - Travniki in pašniki.- Zgodovinsko društvo za južno Primorsko, ZRS-RS Koper, pp. 111, Koper.

Kaligarič, M., \& S. Škornik, 2002: Variety of dry and semi-dry secondary grasslands (Festuco-Brometea) in Slovenia - contact area of different geoelements. Razprave - Slovenska akademija znanosti in umetnosti, Razr. naravoslne vede, 227-246.

Kaligarič, M., Culiberg, M. \& B. Kramberger, 2006: Recent vegetation history of the North Adriatic grasslands: expansion and decay of an anthropogenic habitat.- Folia Geobotanica, 41, 241-258.

Kaligarič, M. \& S. Škornik, 2007: Vegetation of tall rush saltmarshes (Juncetea maritimae) and saltmarsh scrubs (Arthrocnemetea fruticosae) on the Slovenian seacoast.- Annales, 17, 1, 47-58.

Keddy, P.A., 1992: A pragmatic approach to functional ecology.- Functional Ecology, 6, 621-626.

Kleyer, M., Bekker, R.M., Knevel, I.C., Bakker, J.P., Thompson, K., Sonnenschein, M., Poschlod, P., van Groenendael, J.M., Klimes, L., Klimesová, J., Klotz, S., Rusch, G.M., Hermy, M., Adriaens, D., Boedeltje, G., Bossuyt, B., Endels, P., Götzenberger, L., Hodgson, J.G., Jackel, A.K., Dannemann, A., Kühn, I., Kunzmann, D., Ozinga, W.A., Römermann, C., Stadler, M., Schlegelmilch, J., Steendam, H.J., Tack- enberg, O., Wilmann, B., Cornelissen, J.H.C., Eriksson, O., Garnier, E., Fitter, A. \& B. Peco, 2008: The LEDA Traitbase: A database of plant life-history traits of NorthWest Europen flora.- Journal of Ecology, 96, 1266-1274.

Klotz, S., Kuhn, I. \& W. Durka, 2002: BIOLFLOR - Eine Datenbank mit biologisch-okologischen Merkmalen zur Flora von Deutschland. Schriftenr.- Vegetationsk, 38, 1-334.

Lavorel, S., McIntyre, S., Landsberg, J. \& T.D.A. Forbes, 1997: Plant functional classification: from general groups to specific groups based on response to disturbance.- Trends in Ecology and Evolution, 12, 474-478.

Lavorel, S. \& E. Garnier, 2002: Predicting changes in community composition and ecosystem functioning from plant traits: revisiting the Holy Grail.Functional Ecology, 16, 545-556.

Lavorel, S., Grigulis, K., McIntyre, S., Garden, D., Williams, N., Dorrough, J., Berman, S., Quetier, F., Theboult, A. \& A. Bonis, 2008: Assessing functional diversity in the field - methodology matters!- Functional Ecology, 22, 134-147.

Lepš, J., de Bello, F., Lavorel, S. \& S. Berman, 2006: Quantifying and interpreting functional diversity of natural communities: practical considerations matter.- Preslia, 78, 481-501.

Martinčič, A., Wraber, T., Jogan, N., Podobnik, A., Turk, B. \& B. Vreš, 2007: Mala flora Slovenije. Kjuč za določanje praprotnic in semenk.- Tehniška založba Slovenije, pp. 967, Ljubljana.

McIntyre, S., Lavorel, S. \& R.M. Tremont, 1995: Plant life-history attributes: their relationship to disturbance response in herbaceous vegetation.- Journal of Ecology, 83, 31-44.

Mihevc, A., 1997: Kras morphology.- In: Krajnc, A. (ed.) Kras: Slovene classical karst. Znanstvenoraziskovalni center SAZU, Založba ZRC: Inštitut za raziskovanje krasa ZRC SAZU, pp. 43-49, Ljubljana.

Moretti, M., de Bello, F., Roberts, S.P. \& S.G. Potts, 2009: Taxonomical vs functional responses of bee communities to fire in two contrasting climatic regions.Journal of Animal Ecology, 78, 98-108.

Ogrin, D., 1995: Podnebje Slovenske Istre.- Zgodovinsko društvo za južno Primorsko, pp. 381, Koper.

Peco, B., de Pablos, I., Traba, J. \& C. Levassor, 2005: The effect of grazing abandonment on species composition and functional traits: the case of dehesa grasslands.- Basic and applied Ecology, 6, 175-183.

Pipenbaher, N., Kaligarič, M., \& S. Škornik, 2008: Functional comparision of the sub-mediterranean Illyrian meadow from two distinctive geological substrates.- Annales, 18, 247-258. 
Piskernik, M., 1988: Sušna travišča Slovenskega primorja - pred 30 leti. pp. 21, Lokev-Divača.

Piskernik, M., 1991: Gozdna, travniška in pleveliščna vegetacija Primorske.- Inštitut za gozdno in lesno gospodarstvo, Vtozd za gospodarstvo, VDO Biotehniška fakulteta Univerze v ljubljani, Strokovna in znanstvena dela, pp. 106, Ljubljana.

Poldini, L., 1980: Übersicht über die Vegetation des Karstes von Triest und Görz (NO Italien).- Studia Geobotanica, 1, 79-130.

Poldini, L., 1989: La vegetazione del Carso isontino e triestino. Edizioni LINT, pp. 209, Trieste.

Poldini, L. 1991: Atlante corologico delle piante vascolari nel Friuli-Venezia Giulia: inventario floristico regionale. Arti grafiche friulane, pp 897, Udine.

Pyšek, P. \& A. Pyšek, 1991: Succession in urban habitats: an analysis of phytosociological data.- Preslia, 63, 125-138.

Quézel, P. \& F. Medail, 2003: Ecologie et biogeography des forests du basin Mediterranean.- Elsevier, pp. 573, Paris.

Ricotta, C. \& M. Moretti, 2010: Assessing the functional turnover of species assemblageswith tailored dissimilarity matrices.- Oikos, 119, 1089-1098.

Rothmaler, W., 1995: Exkursionsflora von Deutschland.Gustav Fischer Verlag, pp. 753, Jena-Stuttgart.

Schlapfer, M., Zoller, H. \& C. Korner, 1998: Influences of mowing and grazing on plant species composition in calcareous grassland.- Botanica Helvetica, 108, 57-67.

SPSS Inc., 2006: SPSS Base 15.00 User's guite. Chicago, IL: SPSS Inc.

Stammel, B., Kiehl, K. \& J. Pfadenhauer, 2003: Alternative management on fens: Response of vegetation to grazing and mowing.- Applied Vegetation science, 6, 245-254.
Škornik, S., 2001: A contribution to the knowledge of dry grassland vegetation of the Brometalia erecti Koch 1926 order in Slovenia = Prispevek k poznavanju vegetacije suhih travišč reda Brometalia erecti Koch 1926 v Sloveniji.- Acta Biologica Slovenica, 44, 29-43.

Škornik, S., Vidrih, M \& M. Kaligarič, 2010: The effect of grazing pressure on species richness, composition and productivity in North Adriatic Karst pastures.Plant Biosystem, 144, 355-364.

ter Braak, C.J.F. \& P. Šmilauer, 2002: CANOCO Reference Manual and CanoDraw for Windows User's Guide: Software for Canonical Community Ordination (version 4.5). Microcomputer Power, pp. 500, Ithaca NY, USA.

Wallis DeVries, M.F., Poschlod, P. \& J.H. Willems, 2002: Challenges for the conservation of calcareous grasslands in Northwestern Europe: integrating the requirements of flora and fauna.- Biological Conservation, 104, 265-273.

Watts, D., 2004: Quaternary biotic interactions in Slovenia and adjacent regions: the vegetation. In: Griffiths, H.I.B. et al. (eds) Balkan Biodiversity. Pattern and process in the European hotspots. Kluwer, pp. 69-78, Dordrecht.

Westhoff, V. \& E. van der Maarel, 1973: The Braun-Blanquet approach.- Handbook of Vegetable Science, 5, $156-172$.

Westoby, M., 1998: A leaf-height-seed (LHS) plant ecology strategy scheme.- Plant soil, 199, 213-227.

Willems, J.H., 1990: Calcareous grasslands in continental Europe. In: Hiller, S.H. et al. (eds.) Calcareous grasslands: ecology and management. Bluntisham books, pp. 3-10, Huntingdon. 